ZOOLOGIA 28 (1): 115-121, February, 2011

doi: $10.1590 /$ S1984-46702011000100016

\title{
The identity of Myotis punensis (Chiroptera: Vespertilionidae)
}

\author{
Ricardo Moratelli \& Don E. Wilson²
}

\author{
${ }^{1}$ Campus Fiocruz da Mata Atlântica, Fundação Oswaldo Cruz. Rio de Janeiro, Estrada Rodrigues Caldas, 3400, Taquara, \\ Jacarepaguá, Pavilhão Agrícola, 22713-375 Rio de Janeiro, RJ, Brazil. E-mail: rmoratelli@fiocruz.br \\ ${ }^{2}$ National Museum of Natural History, Smithsonian Institution. Washington, D.C., USA. E-mail: wilsond@si.edu
}

\begin{abstract}
Currently twelve species of Myotis Kaup, 1829 (Vespertilionidae: Myotinae) are recognized from South America, with several other named taxa regarded as synonyms, among them Myotis punensis J.A. Allen, 1914. This name was first regarded as a junior synonym of Myotis albescens (É. Geoffroy, 1806) and subsequently of Myotis nigricans (Schinz, 1821). To address the taxonomic status of the holotype of M. punensis, we compared it to all South American species in the genus. The fringe of hairs on the trailing edge of the uropatagium, the fur color, and external and skull dimensions all suggest $M$. punensis should be treated as a junior synonym of M. albescens.
\end{abstract}

KEY WORDS. Ecuador; Myotinae; Myotis albescens; Myotis esmeraldae; synonymy.

Myotis Kaup, 1829 (Vespertilionidae: Myotinae) comprises a diverse group of small to large-sized vespertilionid bats with a worldwide distribution, including more than one hundred species (Simmons 2005). Twelve South American species are recognized currently (WiLson 2008). Nevertheless, about 60 names have been proposed for South American Myotis since the description of the first species from that continent, Myotis albescens (É. Geoffroy, 1806), more than two centuries ago. Among them, Myotis punensis J.A. Allen, 1914 was described based on a single specimen from Isla Puna, Ecuador.

Miller \& Allen (1928) regarded the name Myotis punensis as a junior synonym of Myotis albescens. Later LAVAL (1973) identified the holotype of M. punensis as M. nigricans (Schinz, 1821). LAVAL (1973) applied the name Myotis punensis to populations of $M$. nigricans from lowland localities on the west side of the Andes in Colombia, Ecuador, and Peru, recognizing them at the subspecific level as M. nigricans punensis J.A. Allen, 1914. Subsequently, Bogan (1978) refuted the distinctness of those populations and recommended that the name Myotis nigricans punensis should be relegated to the synonymy of Myotis nigricans nigricans, but without examining the holotype of M. punensis. Bogan's (1978) suggestion was followed by Simmons (2005) and Wilson (2008), who considered Myotis punensis a junior synonym of Myotis nigricans.

As part of an ongoing systematic and biogeographic review of South American species of Myotis and in order to further investigate the identity of M. punensis, we compared its holotype with the South American species of Myotis currently recognized.

\section{MATERIAL AND METHODS}

We evaluated the taxonomic status of M. punensis by comparing its holotype (AMNH 36263) to the currently recognized
South American species of Myotis, represented by their type specimens, original descriptions, redescriptions provided by LAVAL (1973) and comparative series from different localities. The type specimens used in comparisons were: M. albescens (AMNH 205195, neotype), M. levis levis (I. Geoffroy, 1824) (MNHN type no. 203, lectotype), M. keaysi keaysi J.A. Allen, 1914 (AMNH 15814, holotype), M. nesopolus larensis LaVal, 1973 (AMNH 130709, holotype), M. riparius Handley, 1960 (USNM 310255, holotype) and M. ruber (É. Geoffroy, 1806) (USNM 115097, neotype). The original descriptions used in comparisons were: M. aelleni Baud, 1979, M. atacamensis (Lataste, 1892), M. chiloensis (Waterhouse, 1840), M. levis dinellii (Thomas, 1902), M. keaysi pilosatibialis LaVal, 1973, M. nigricans nigricans (Schinz, 1821), M. oxyotus (Peters, 1867) and M. simus Thomas, 1901. A list of specimens examined and their localities is in the Appendix 1. A set of qualitative and quantitative characters reported as diagnostic by previous authors (Thomas 1901, 1902, Miller \& Allen 1928, Handley 1960, LaVal 1973, Baud \& Menu 1993, López-GonZÁlez et al. 2001, López-GonZÁLez 2005, Wilson 2008) were used in comparisons. The qualitative characters selected were: plagiopatagium attachment (attached at ankles; at toes by a narrow band of membrane; or at toes by a broad band of membrane); occurrence of a fringe of hairs along the trailing edge of the uropatagium (absent or present); position of P3 (aligned with other premolars or displaced to the lingual side, and visible or not visible when observed in lateral view); occurrence and height of sagittal and occipital crests (absent or present; and height: very low, low, medium and high); shape of the braincase roof (parietal inclined forward or straight when observed in lateral view); shape of the supraoccipital region (supraoccipital and posteriormost part of parietals flattened when observed in lateral view, not projecting much beyond the limit of the occipital condyles, or supraoccipital and 
posteriormost part of parietals rounded, projecting beyond the limit of the occipital condyles).

Nine cranial and four external dimensions were measured using a digital caliper accurate to $0.02 \mathrm{~mm}$. The measurements, reported in millimeters $(\mathrm{mm})$, and their abbreviations are defined as follows (lengths were measured from the anteriormost point of the first structure to the posteriormost point of the second structure mentioned below): zygomatic breadth, greatest breadth across the outer edges of the zygomatic arches; interorbital breadth, least breadth dorsally between the orbits; postorbital breadth, least breadth across frontals posterior to the postorbital bulges; breadth across canines, greatest breadth across outer edges of the crowns of upper canines including cingulae; breadth across molars, greatest breadth across outer edges of the crowns of upper molars; maxillary toothrow length, from the upper canine crown including cingulum to the crown of M3; molariform toothrow length, from the crown of M1 to the crown of M3; mandibular length, from the line of internal incisors, to the angular process; mandibular toothrow length, from the lower canine to $\mathrm{m} 3$; forearm length, from the elbow to the distal end of the forearm including carpals; third metacarpal length, from the distal end of the forearm to the distal end of the third metacarpal; and length of the dorsal and ventral hairs, from the base to the tip of the hair, measured between scapulas. Other measurements that characterize the length of skull were not used due the condition of the skull, which lacks parts of the posterior region.

\section{TAXONOMY}

\section{Redescription of the holotype of Myotis punensis}

The holotype of Myotis punensis (AMNH 36263) was collected by W.B. Richardson on Isla Puna, Guayaquil, Guayas, Ecuador ( $2^{\circ} 12^{\prime} \mathrm{S}, 80^{\circ} 01^{\prime} \mathrm{W}$ [GARDNer 2008]), sea level, on 8 May, 1913. The specimen, currently deposited in the mammal collection at American Museum of Natural History, is a sub-adult male (sensu Simmons \& Voss 2009), skin and skull preserved, including the mandible. The left side of the skull is broken, lacking parts of the parietal, interparietal, supraoccipital, squamosal, occipital condyle, basioccipital, and ectotympanic.

The holotype is a small specimen (forearm length 31.6 $\mathrm{mm}$ ) with small ears (less than $12 \mathrm{~mm}$ ) and long, silky pelage (length of dorsal fur $7.3 \mathrm{~mm}$; ventral fur $5.4 \mathrm{~mm}$ ). The dorsal fur is distinctly bicolored with medium-brown bases (more than $2 / 3$ of total length) and light-brown tips. The ventral fur is strongly bicolored with dark-brown bases ( $2 / 3$ of total length) and yellow tips. There is more contrast between bases and tips in the ventral fur than in the dorsal fur. The membranes are medium brown and there is a weak fringe of hairs along the trailing edge of the uropatagium. The plagiopatagium appears to be attached at feet (Fig. 1). The skull is small (mandibular length $9.04 \mathrm{~mm}$ ) and the braincase is long and flattened. The supraoccipital region is rounded and the sagittal crest is very low. There are no occipital crests and the third upper premolar is in the toothrow, not crowded to the lingual side (Fig. 2).

The measurements of the holotype are: zygomatic breadth: 8.18 ; interorbital breadth: 4.12 ; postorbital breadth: 3.56; breadth across canines: 3.18 ; breadth across molars: 4.90 ; maxillary toothrow length: 4.62 ; molariform toothrow length: 2.69; mandibular length: 9.04; mandibular toothrow length: 5.11; forearm length: 31.6; third metacarpal length: 29.8; length of the dorsal hairs: 7.3; and length of the ventral hairs: 5.4.

Based on external and skull measurements reported by LAVAL (1973) and López-González et al. (2001) for South American Myotis, the holotype of M. punensis overlaps in size with specimens of $M$. atacamensis, M. nigricans and M. albescens among its South American congeners (LaVAL 1973). Myotis punensis can be distinguished from the species above, except M. albescens, based on the fringe of hairs along the trailing edge of the uropatagium, a character shared only by M. albescens and M. levis among South American Myotis (LAVAL 1973, WILson 2008). Although some hairs may be present along the edge of the uropatagium in some specimens of $M$. nigricans and $M$. oxyotus, they do not form the fringe observed in M. albescens and M. levis. The holotype of M. punensis can be distinguished from $M$. levis primarily by its smaller overall size, smaller ears (ranging from 12-19 $\mathrm{mm}$ in M. levis) and lighter ventral fur coloration. In addition, M. levis is reported only from Bolivia, Argentina, Uruguay, and Brazil, occurring from $20^{\circ} \mathrm{S}$ toward southward (LaVal 1973, Simmons 2005, Wilson 2008). On the other hand, some of the main diagnostic characters in $M$. albescens are the ear length $(9-14 \mathrm{~mm})$, long and silky pelage, tips of dorsal pelage with frosted appearance, and fringe of hairs along the trailing edge of uropatagium (LAVAL 1973, LópezGonZÁlez et al. 2001, BRAUn 2009), all of which are present in the holotype of M. punensis. Additionally, M. albescens is widely distributed in South and Central America.

\section{DISCUSSION}

Allen (1914) described M. punensis as smaller but similar in coloration to M. albescens. Subsequently, Miller \& AlleN (1928) considered M. punensis a junior synonym of M. albescens. On the other hand, LAVAL (1973) regarded M. punensis as a subspecies of M. nigricans. Subsequently, Bogan (1978) regarded M. punensis as a junior synonym of $M$. nigricans, a decision followed by Simmons (2005) and WiLson (2008). In this study, based on overall external and skull size, tips of dorsal pelage with frosted appearance and presence of a fringe of hairs along the trailing edge of the uropatagium in the holotype of $M$. punensis, we suggest that the name Myotis punensis J.A. Allen, 1914 should be regarded as a junior synonym of Myotis albescens (É. Geoffroy, 1806), as formerly proposed by Miller \& Allen (1928).

We did not examine other specimens assigned to $M$. $n$. punensis by LaVAL (1973). Bogan (1978), however, did analyze part of the Colombian and Ecuadorian samples assigned to $M$. $n$. punensis by LAVAL (1973). Based on a multivariate analysis of 

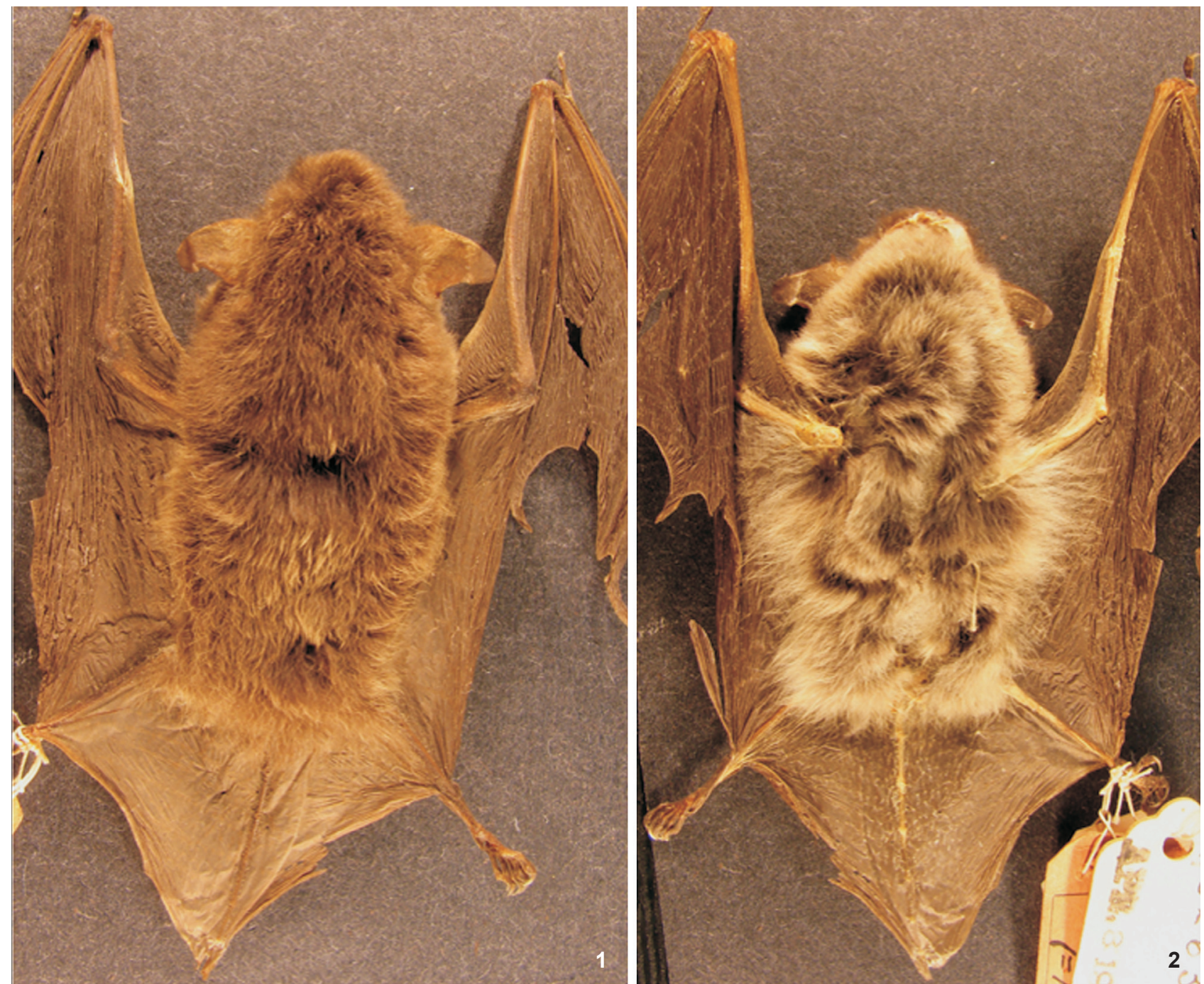

Figure 1. Dorsal and ventral views of the skin of the holotype of Myotis punensis (AMNH 36263). Forearm length $31.6 \mathrm{~mm}$. The electronic version of this article includes this figure in color.

cranial and external morphology, Bogan (1978) refuted the distinctness of those samples in relation to other South American samples of M. nigricans. Based on Bogan's (1978) results other specimens assigned to M. $n$. punensis by LAVAL (1973) probably are M. nigricans. Despite the conclusions of LAVAL (1973) and Bogan (1978), if those populations on the west side of the Andes ultimately should prove to be distinct from populations assigned to M. nigricans nigricans by LAVAL (1973), as well as from other currently recognized South American species, the name Myotis punensis J.A. Allen, 1914, is not available for them, as it is a junior synonym of Myotis albescens (É. Geoffroy, 1806). A possible name for those populations is Myotis esmeraldae J.A. Allen, 1914, a name currently in the synonymy of Myotis nigricans.

\section{ACKNOWLEDGEMENTS}

The following curators and collection staff provided access to specimens under their care: Adriano L. Peracchi (Universidade Federal Rural do Rio de Janeiro, Brazil), João Alves de Oliveira, Stella M. Franco (Museu Nacional, Brazil), Fernando de C. Passos (Universidade Federal do Paraná, Brazil), Teresa C. Margarido (Museu de História Natural Capão da Imbuia, Brazil), Mario de Vivo, Juliana Barros (Museu de Zoologia da Universidade de São Paulo, Brazil), Eliana MorielleVersute (Universidade Estadual Paulista "Julio de Mesquita Filho", Brazil), Nancy Simmons, Eileen Westwig (American Museum of Natural History, USA), Linda Gordon (National 


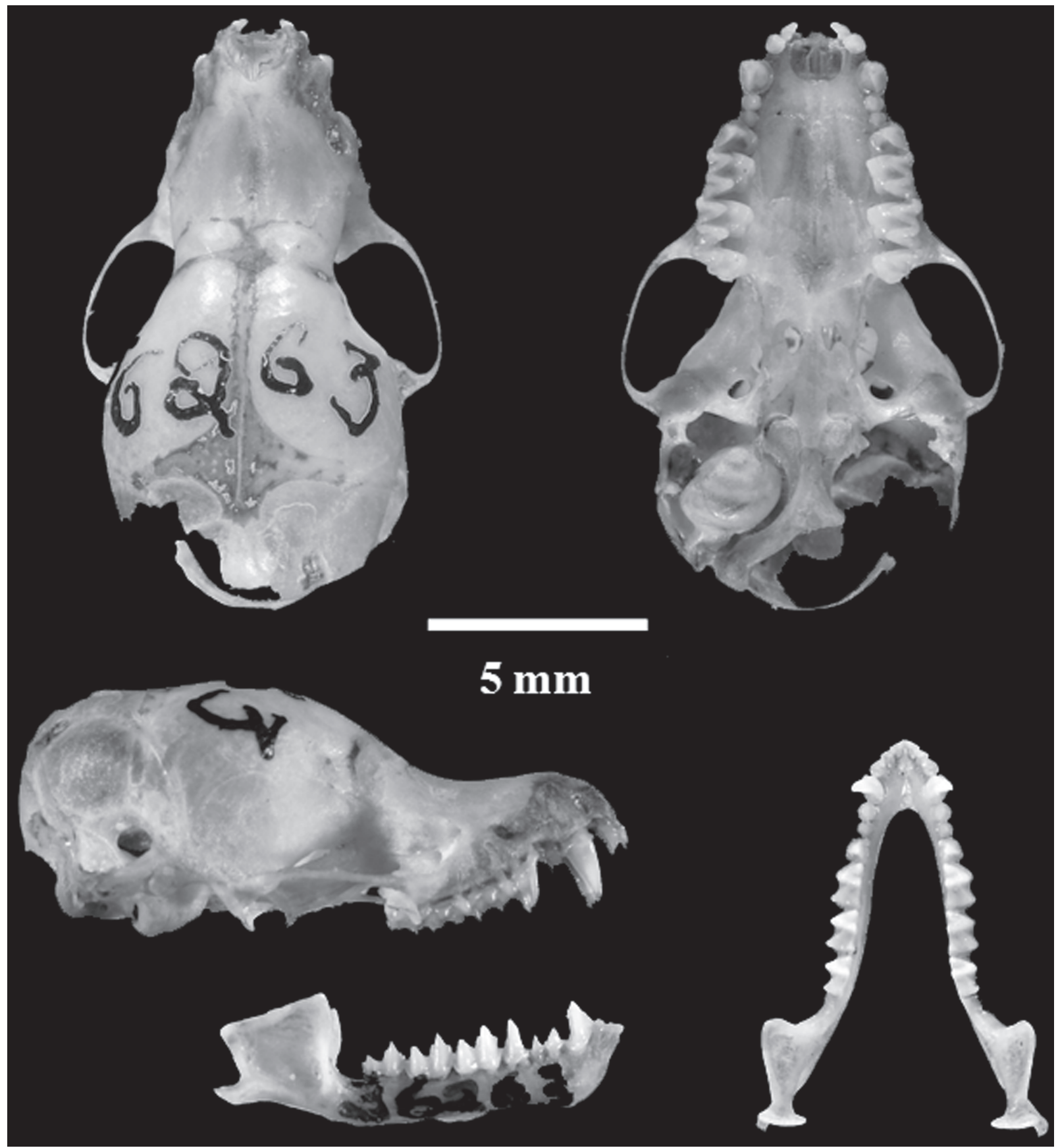

Figure 2. Dorsal, ventral and lateral views of the cranium and dorsal and lateral views of the mandible of the holotype of Myotis punensis (AMNH 36263). See text for measurements.

Museum of Natural History, USA), Alfred Gardner (USGS Patuxent Wildlife Research Center, USA), and Patrick Boussès (Muséum national d'Histoire naturelle, France). Nancy Simmons permitted the use of the images of the holotype. RM was partially supported by a scholarship from Coorde- nação de Aperfeiçoamento de Pessoal de Ensino Superior (Ministério da Educação, Brazil), and by Short-Term Visitor and Collection Study grants respectively from the National Museum of Natural History and the American Museum of Natural History. 


\section{LITERATURE CITED}

AlLen, J.A. 1914. New South American bats and a new octodont. Bulletin of the American Museum of Natural History 33, 381-389.

Baud, F.J. \& H. Menu. 1993. Paraguayan bats of the genus Myotis, with a redefinition of Myotis simus (Thomas, 1901). Revue Suisse de Zoologie 100, 595-607.

Bogan, M.A. 1978. A new species of Myotis from the Islas Tres Marias, Nayarit, Mexico, with comments on variation in Myotis nigricans. Journal of Mammalogy 59 (3): 519-530.

Braun, J.K.; Q.D. Layman \& M.A. Mares. 2009. Myotis albescens (Chiroptera: Vespertilionidae). Mammalian Species 846: 19.

Gardner, A.L. 2008. Mammals of South America. Chicago, The University of Chicago Press, vol. 1, XIX+669p.

Handley JR, C.O. 1960. Descriptions of new bats from Panama. Proceedings of the United States National Museum 112: 459-479.

LAVAL, R.K. 1973. A revision of the Neotropical bats of the genus Myotis. Natural History Museum, Los Angeles County, Science Bulletin 15: 1-54.

López-GonZÁlez, C. 2005. Murciélagos de Paraguay. Biosfera 9: $1-316$.

López-González, C.; S.J. Presley; R.D. Owen \& M.R. Willig. 2001. Taxonomic status of Myotis (Chiroptera: Vespertilionidae) in Paraguay. Journal of Mammalogy 82 (1): 138-160.

Miller, G.S. \& G.M. Allen. 1928. The American bats of the genera Myotis and Pizonyx. Bulletin of the United States National Museum 144: 1-128.

Simmons, N.B. 2005. Order Chiroptera, p. 312-529. In: D.E. WILSON \& D.M. ReEder (Eds). Mammal Species of the World: a taxonomic and geographic reference. Baltmore, The Johns Hopkins University Press, $3^{\text {rd }}$ ed., 2142p.

Simmons, N.B. \& R.S. Voss. 2009. Collection, preparation, and fixation of specimens and tissues, p. 849-867. In: T.H. KunZ $\&$ S. PARSONS (Eds). Ecological and behavioral methods for the study of bats. Baltimore, The Johns Hopkins University Press, $2^{\text {nd }}$ ed., XVII+901p.

Thomas, O. 1901. New Myotis, Artibeus, Sylvilagus and Metachirus from South America. The Annals and Magazine of Natural History Series 7 (7): 189-193.

Thомаs, O. 1902. On Azara's "Chauve-souris onzieme" (Myotis ruber, Geoff.) and a new species allied to it. The Annals and Magazine of Natural History Series 7 (10): 494-495.

Wilson, D.E. 2008. Genus Myotis Kaup 1829, p. 468-481. In: A.L. Gardner (Ed.). Mammals of South America. Chicago, University of Chicago Press, XIX+669p.

Submitted: 18.X.2010; Accepted: 30.XII.2010.

Editorial responsibility: Diego A. de Moraes

Appendix 1. Specimens examined: Abbreviations of institutions are as follows: Museu Nacional, Rio de Janeiro, Brazil (MN); Universidade Federal Rural do Rio de Janeiro, Seropédica, Brazil (ALP); Museu de Zoologia, São Paulo, Brazil (MZUSP); Universidade do Estado de São Paulo, São José do Rio Preto, Brazil (DZSJRP); Museu de História Natural Capão da Imbuia, Curitiba, Brazil (MHNCI); Universidade Federal do Paraná, Curitiba, Brazil (CCMZ-DZUP); American Museum of Natural History, New York, USA (AMNH); National Museum of Natural History, Washington, DC, USA (USNM); and Museum National d'Histoire Naturelle, Paris, France (MNHN). The abbreviation JAO corresponds to field numbers of João Alves de Oliveira (Museu Nacional, Brazil), and those specimens will be deposited in mammal collection at Museu Nacional.

Myotis albescens: BolIVIA, Beni: Mamore - AMNH 209765, 209767, 209769, 209770, 210964, 210965, 210966, 210967, 210968, 210969, 210970, 210971, 210972, 210973, 210975, 210976, 210977, 210978, 210979. Beni: Marban - AMNH 210963. Beni: Vaca Diez 209768. Beni: Yacuma - AMNH 210980, 210981, 210982, 210983, 210984, 210985, 210986, 210987, 210988, 210989. Cochabamba: Chapare - AMNH 268648. Santa Cruz, Andres Ibanez - AMNH 264081. Santa Cruz: Sara - AMNH 246414. Rosario: unknown locality - USNM 238686. BrASIL, Amazonas: Airão - AMNH 79530, 79531, 79702, 79703, 79704, 79705, 79706, 79707, 79708, 79709, 79710, 79711, 79712, 79713, 79714, 79715, 79716, 79717, 79718, 79719, 79720. Amazonas: Borba - AMNH 91905, 91906, 91909, 91910, 92229. Amazonas: Humaitá - DZSJRP 14113, 14114, 14119, 14780. Amazonas: Manicoré - AMNH 92665, 92666, 92667, 92668, 92670, 92675, 92677, 92678, 92679, 92680, 92681. Amazonas: São Gabriel da Cachoeira - AMNH 77384, 77385, 77386, 77387, 77388, 77389, 77390, 77391, 77392, 77393, 77394, 77395, 77396, 77397, 77398, 77399, 77400, 77401, 77402, 77403, 77404, 77405, 78751, 78752, 78753, 78754, 78755, 78756, 78757, 78758, 78759, 78760, 78761, 78762, 78763, 78764, 78765, 78766, 78767, 78768, 78769, 78770, 78771, 78772, 78773, 78774, 78775, 78776, 78777, 78778, 78779, 78780. Pará: Altamira - MZUSP 22690, 22692, 22705, 22708, 22738, USNM 549511, 549512, 549513, 549514, 549515, 549516. Pará: Aveiro AMNH 94448, 94449, 94450, 94451, 94454, 94455, 94456, 94457, 94458. Pará: Baião - AMNH 97087, 97088, 97089, 97090, 97091, 97092, 97093, 97094, 97095, 97096, 97097, 97098, 97099, 97123, 97124, 97125, 97126, 97127, 97273, 97274. Pará: Belém - USNM 361774, 361775, 361776, 361777, 361778, 361779, 393764, 460137, 460138. Pará: Faro - AMNH 93926, 93927, 93928, 93929, 93930, 93931, 93932, 93933, 93934, 93935, 93936, 93937, 93938. Pará: Porto de Móz - AMNH 96102, 96103, 96104, 96105, 96106, 96107, 96108, 96109, 96110, 96111, 96112, 96113, 96114, 96115, 96116, 96117, 96118, 96119, 96120. Pará: Santarém - AMNH 94444, 94445, 94446, 94447, 94453. Pará: Tapajós River - AMNH 94459, 94460, 94461, 94462, 94463, 
94464, 94465, 94466, 94467, 94468, 94469, 94470, 94471, 94472. Paraná: Mangueirinha - MHNCI-CTX 3958. Paraná: Maringá DZSJRP 10510. Paraná: Paiçandu - DZSJRP 10458, 10459, 10460, 10524, 10525, 10550, 10551, 10552, 10553, 10554, 10555, 10556, 10557, 10558, 10559, 10560, 10561, 10562, 10563, 10564, 10565, 10566, 10567, 10568, 10569, 10570, 10571, 10572, 10573, 10574, 10575, 10576. Paraná: Piraquara - MHNCI 1802. Paraná: Porto Rico - CCMZ-DZUP 226. Paraná: Quatro Barras MHNCI-CTX 4923. Rio de Janeiro: Piraí - ALP 4659, 5165. Rio Grande do Sul: Taim - DZSJRP 14556, 14557. Roraima: Maracá - MZUSP 26849. São Paulo: Atibaia - DZSJRP 14432. São Paulo: Avanhandava - MZUSP 1292, 22691. São Paulo: Fernando Prestes - DZSJRP 13609, 13612, 13617. São Paulo: Itatiba - DZSJRP 12590. São Paulo: near Registro - DZSJRP 12554. ColombIA, Valle del Cauca: Zabaletas - USNM 483946. Ecuador, Guayas: Isla Puna - AMNH 36263. Guiana Francesa, unknown locality: MZUSP 7647. Paraguay, Asuncion: Asuncion - MZUSP 2024. Boqueron: Parque Nacional Teniente Enciso - USNM 555671. Canindeyu: Curuguaty - AMNH 234317, 234318, 234319, 234320, 234323, 234324, 234326, 234328, 234329, 234330, 234332, 234333, 234334, 234336. Cordillera: Tacuaral - USNM 105562, 105563, 105564, 105565, 105566, 105567, 105568, 105569, 105570, 105571, 105572, 105575, 105576, 105577, 105578, 105579, 105580, 105581, 105582, 105583, 105584, 105585, 105661, 105662, 105664. Paraguari: Yaguaron AMNH 205195. PERU, Loreto: Maynas - AMNH 73235, 73237, 73239, 73242, 74018, 74019, 74021. Loreto: unknown locality - AMNH 71643. Madre de Dios: Paktiza - USNM 564391, 564392, 566560, 566561, 566562, 566563. Pasco: Oxapampa - AMNH 230746, 230747, 230748, 230750, 230751, 230752, 230753, 230754, 230755, 230756, 230757. Pasco: San Juan - USNM 364442, 364443, $364444,364445,364446,364447,364448,364449,364450,364451,364452,364453,364454,364455,364456,364457,364458$, 364459, 364460, 364461, 364462, 364463, 364464, 364465, 364466, 364467, 364468, 364469, 364470, 364471, 364472, 364473, 364474, 364475, 364476, 364477, 364478, 364479, 364480. Pasco: unknown locality - AMNH 213428, 213430. URUGUAY, Artigas: Belén - AMNH 205454, 205456, 205458, 205459, 205460, 205462, 205463, 205465, 205466, 205468, 205469, 205470, 205473, 205474, 205475. VenezUela, Amazonas: Belen - USNM 405790, 405792, 405794, 405796. Amazonas: Capibara - USNM 409392, 409395, 416579. Amazonas: Cerro Neblina - USNM 560807, 560808. Amazonas: Porto Ayachuco - USNM 409416, 409420, 409422, 409425. Amazonas: Rio Mavaca - USNM 405798. Amazonas: San Juan - USNM 409403, 409404, 409406, 409407, 409408, 409410, 409411, 409412, 409413, 409414, 409415, 409454, 416580, 416581, 416582. Apure: Nulita - USNM 441714, $441715,441716$. Apure: Porto Paez - USNM 373909, 373913, 373914, 373915, 373916, 373917, 374008. Bolivar: Rio Supamo - USNM 387693. Miranda: Porto Tuy - USNM 387697, 387698, 387699, 87700, 387701, 387702, 387703. Trujillo: Valera - USNM 370933. Zulia: El Rosario - USNM 441718.

Myotis chiloensis: CHILE, Coastal Town N of Valparaíso: Zapallar - USNM 391785.

Myotis keaysi keaysi: BoliviA, Santa Cruz: Vallegrande - AMNH 260880, 262647. Peru, Cuzco: Cordillera Vilcabamba - AMNH 214371, 233850, 233851, 233853, 233854, 233857, 236134. Huánuco: Huánuco: AMNH 216117. Puno: Inca Mines - AMNH 15814. VeneZUeLA, Aragua: 13 km NW of Maracay (Rancho Grande Biological Station) - USNM 370901. Bolívar: Gran Sabana - AMNH $130625,130626$.

Myotis keaysi pilosatibialis: VeneZUeLA, Aragua: 13 km NW of Maracay (Rancho Grande Biological Station) - USNM 370929, 562920, 562921. Carabobo: Montalbán - USNM 441741, 441742. Miranda: Curupao - USNM 387714, 387715, 387716, 387718.

Myotis levis dinellii: ARGENTINA, Córdoba: USNM 142560, 142561, 142562. Tucumán: La Rocha - AMNH 256987. BoLIVIA, Cochabamba: AMNH 261119. Chuquisaca: Tomina - AMNH 263629. Santa Cruz: Caballero - AMNH 260253. Potosí - AMNH 39003.

Myotis levis levis: ARGENTINA, Buenos Aires: La Valle - USNM 236236, 236237. Córdoba - USNM 252766. Tucumán: Los Vásquez - MZUSP 2055. Entre Ríos: Puerto Constanza - USNM 582461. BraZIL, Minas Gerais: Mariana - MZUSP 1748. Minas Gerais: Ouro Preto MZUSP 15344, 15345. Paraná: Palmas - CCMZ-DZUP 380. Paraná: Porto Rico - CCMZ-DZUP 216, 217, 218, 369, 371, 372, 373, $376,377,381,382,384,385,386,387,388,389,391,392,393,394,395,396$. Rio de Janeiro: Nova Friburgo - MZUSP 2799. Rio de Janeiro: Teresópolis - ALP 6481, 6523. Rio Grande do Sul: Camapuã - AMNH 235863, 235864, 235865, 235866, 235867, 235868, 235869, 235870, 235871, 235872, 235873, 235874, 235875, 235876, 235877, 235878, 235879, 235880, 235881. Rio Grande do Sul: Harmonia - AMNH 235892. Rio Grande do Sul: São Leopoldo - DZSJRP 10393. Rio Grande do Sul: Taim - DZSJRP 14548, 14549, 14550, 14552, 14553, 14554, 14555. Santa Catarina: Passos Maia - CCMZ-DZUP 333, 334, 335, 336. São Paulo: Boracéia - MZUSP 15224, 15225, 15273, 15274, 15304, 15305, 15306, 15307, 15308, 15309, 15358, 27491. São Paulo: Cacequí - MZUSP 3167. São Paulo: Cananéia - MZUSP 27680, 27976. São Paulo: Casa Grande - MZUSP 16473, 16474, 16475, 16476, 16477, 16478, 16479, 16480, 16481, 16482, 16483, 16484, 16485, 16486, 16487, 16488, 16489, 16490, 16491, 16492, 16493, 16494, 16495, 16496, 16497, 16498, 16499, 16500, 16501, 16502, 16503, 16504, 16505, 16506, 16507, 16508, 16509, 16510, 16477. São Paulo: Itapeva - DZSJRP 11364, 11365. Unknown locality - MNHN type 203. URUGUAY, Lavalleja: Piraraja - AMNH 205477, 205478, 205503, 205504, 205505, 205508, 205509, 205510, 205511, 205512, 205513, 205514, 205515. Tacuarembó: Yaguari - MZUSP 28979, 28981. Colón - USNM 252599. Unknown locality - MZUSP 10084, USNM 102588, $102589,102590$.

Myotis nesopolus: VeNEZUELA, Lara: Rio Tucuyo - USNM 441710. Falcón: Capatárida - USNM 441711, 441728, 441735, 441736, 441737, 441740. Zulia: Cojoro - USNM 441721.

ZOOLOGIA 28 (1): 115-121, February, 2011 
Myotis nigricans nigricans: BoLIVIA, Cochabamba: Chapare - AMNH 211214, 211215, 211216, 211217, 211218, 211219, 211220, 211221, 211222, 211223, 211226, 211227, 211228, 211229, 211243, 211244, 211245, 211246. Santa Cruz: El Refugio - USNM 584500, 584501. BraZIL, Amazonas - MZUSP 6091. Mato Grosso do Sul: Rio Brilhante - DZSJRP 12220. Mato Grosso do Sul: Pantanal - CCMZDZUP 170, 172, 174, 176, 177. Minas Gerais: Caxambu - ALP 2182. Minas Gerais: Pains - USNM 391131. Minas Gerais: Sete Lagoas - USNM 391129. Minas Gerais: Viçosa - USNM 391132, 391133, 391135. Paraná: Balsa Nova - CCMZ-DZUP 196, 197, 198, 199, 200, 410, 419, 420, 421, 422. Paraná: Matinhos - CCMZ-DZUP 141, 142, 144, 148. Paraná: São José dos Pinhais - CCMZ-DZUP 428. Rio de Janeiro: Tinguá - ALP 2505, 2870, 6262, 6619, 6620, 6624, 6625, 6679, 6682. Rio de Janeiro: Itaguaí - ALP $2284,2290$. Rio de Janeiro: Piraí - ALP 4587, 4783. Rio de Janeiro: Rio de Janeiro - ALP 3047, 3048, 3049, 3050. Rio de Janeiro: Seropédica - ALP $585,588,589,625,626,627,628,629,630,631,636,639,640,655,658,904,1396,1826,2862,3427,3428,3498,3499$, $3581,3697,3703,3705,3715,3716,3718,3723,3740,3741,3742,3744,4815,4816,4817,4819,4825,4827,4839,4844$, 4906, 4930, 4931, 4938, 4939, 4940, 4943, 4944, 4947, 4949, 4950, 5012, 5017, 5020, 5032, 5033, 5034, 5036, 5037, 5040, $5043,5044,5045,5068,5074,5075,5089,5090,5092,5094,5095,5097,5098,5102,5103,5105,5130,5131,5132,5134$, $5171,5172,5173,5174,5175,5176,5179,5180,5181,5185,5186,5187,5188,5235,5327,5331,5332,5338,5340,5341$, 5342, 5344, 5346, 5347, 5348, 5349, 5350, 5499, 5501, 5504, 5510, 5511, 5520, 5521, 5523, 5525, 5543, $5592,5593,5594$. Rio de Janeiro: Teresópolis - ALP 6479, 6524. Rio Grande do Sul: Frederico Westphalen - CCMZ-DZUP 338. Santa Catarina: Passos Maia - CCMZ-DZUP 400. São Paulo: Botucatu - ALP 2270, 2271. São Paulo: Fernando Prestes - DZSJRP 13616, 13619. São Paulo: São José do Rio Preto - DZSJRP 14979. São Paulo: São Sebastião - USNM 141395, 141396, 141398, 141400, 141401, 141403, 141405, 141406, 141408, 141409, 141411, 141412, 141413, 141414. ColombiA, Magdalena: Bonda - AMNH 14587. La Nariño: Ricuarte - USNM 309020. La Nariño: Guayacana - USNM 309021, 309023. EcuAdor, Esmeraldas, AMNH 33239. Pichincha: Santo Domingo - USNM 528566. Zamora-Chinchipe: Cumbaratza - USNM 513488, 513489. Zamora-Chinchipe: Los Encuentros - USNM 513490. San Javier - USNM 113343. Pambilar - USNM 113345, 113346. Paramba - 113349. GuYANA, Upper Demerara-Bernice USNM 582351, 582352. Panama, Canal Zone: Barro Colorado Island - USNM 296266, 296270, 296271, 296272, 296273. Darién: Boca de Cupe - USNM 306796. Darién: Jaque - USNM 306796, 363085, 363086, 363087, 363088. Unknown locality - AMNH 18736. Paraguay, Paraguarí - USNM 115078, 115080. Boquerón (Parque Nacional Teniente Enciso) - USNM $555673,555674$. Paraguarí: Sapucay - USNM 115073, 115089, 121477. Paraguarí (Ibicuy National Park) - USNM 531197. Peru, Amazonas: Cordillera Del Condor - USNM 581966, 581967. VenezuelA, Amazonas: Boca Mavaca - USNM 405801. Amazonas: Ayacucho - USNM 409424, 409455. Apure: Nulita - USNM 441722. Bolívar: Maripa - USNM 17069. Carabobo: Urama - USNM 373921, 373922, 373923, 373924, 373926, 373929, 373932, 373933, 373935, 373936, 373942, 373943, 373946, 373948, 373950. Monagas: San Agustín - USNM 409391, 409429, 409430, 409431, 409433, 409435, 409437, 409438. Yaracuy: Urama - USNM 387708.

Myotis oxyotus: ColombIa, Nariño: El Guabo - USNM 309019. ECUADOr, Chimborazo: Pallatanga - USNM 513480. Pastaza: Mera - USNM 548337, 548339. Pastaza: Mirador - USNM 513491, 513492, 513493, 513494. Peru, Junín: Río Palca - USNM 507204. Cuzco: Iquente - USNM 195196. Cuzco: Santa Ana - USNM 194452, 194453, 195141, 195147, 195149. Venezuela, Amazonas: Cerro Neblina - USNM 560809, 560810, 560811. 85 Km SSE Bolívar: El Dorado - USNM 387712. Mérida: Tabay - USNM 373919.

Myotis riparius: BrazIL, Mato Grosso: Cachoeira São Simão - MN 3757. Mato Grosso do Sul: Paranaíba - DZSJRP 12022. Pará: Altamira USNM 549517, 549518. Pará: Belém - USNM 361786, 361788, 361789, 361790, 361791, 460139. Pará: Mocambo - ALP 1915, 2002, 2003, 2004, 2554, 2557, 2562, 2568, 2587, 2610, 2710. Rio de Janeiro: Tinguá - ALP 4356, 4357, 5421, 6622, 6680, 6681. Rio de Janeiro: Piraí - ALP 4573. São Paulo: Buri - MZUSP 32968, 32969, 32970. São Paulo: Juquitiba - MZUSP 32963, 32964, 32966. São Paulo: São Paulo - MZUSP 31466.

Myotis ruber: BrazIL, Minas Gerais: Viçosa - USNM 391138, 391139, 391140. Rio de Janeiro: Tinguá - ALP 6621, 6623, 6683. Rio de Janeiro: Macaé de Cima - JAO 1751, 1756, 1773. Rio de Janeiro: Teresópolis - ALP 6452, 6457, 6458, 6497, 6499, 6506, 6512, MN 3400. Rio Grande do Sul: São Lourenço do Sul - MZUSP 1298, 1988. São Paulo: Boracéia - MZUSP 28359, 28367, 28368. São Paulo: Buri - MZUSP 32971, 32972, 32973, 32975. São Paulo: Cananéia - MZUSP 27595. São Paulo: São Paulo - MZUSP 15254, 31470, 31471, 31472, 31473, 31971. Unknown locality - DZSJRP 17014.

Myotis simus: BoliviA, Beni: Cercado - AMNH 211155, 211156, 211167, 211168, 211169, 211170, 211171, 211172, 211173, 211174, 211178, 211179, 211180, 211181, 211182, 211183, 211190, 211192, 211193, 211194, 211195, 211196, $211197,211198$. Santa Cruz: El Refugio - USNM 584502. BrazIL, Amazonas: Borba - AMNH 91886, 91887, 91888, 91889, 91890, 91891, 91892, 94224, 94225, 94227, 94230, 94231, 94232, 94233, 94234. Amazonas: Itacoatiara - MZUSP 3472. Amazonas: Manaus - AMNH 79534, 91472, 91473, 91474, 91475, 91476, 91477, 91478, 91500. Amazonas: Parintins - 92983, 93489, 93490, 93491, 93492, 93493, 93494, 93495, 93496, 93497, 93922, 93923, 93924, 93925. Amazonas: Rio Juruá - MZUSP 638, 1074. Mato Grosso: Taiamã - MZUSP 13815. PERU, Loreto: Maynas - AMNH 71483, 71485, 71486, 71487, 71488, 71490, 71491, 71492, 71493, 71494, 74105, 74109, 74110, 74378, 74379, 74380, 74381. Loreto: Ucayali - AMNH 76240, 76241, 76242, 76243, 76244, 76245, 76246, 76247, 76248, 76249, 76252, 76253. Pasco: San Juan - USNM 364481, 364482. 